\title{
Unpacking the influence of social norms and past experience on commute mode choice
}

\section{Matt Biggar*}

\begin{abstract}
Researchers have identified the need for further study of subjective and social influences on personal transportation choices. Set in a workplace-based commute alternative program, this study examines the impact of transportation-related social context and past transportation experience on commute mode choice. Through a purposive, paired sample design with ten individuals, this qualitative study examines influences on commute behavior using narrative interviews and a commute documentation activity. The five pairs of individuals were matched across variables in such a way as to hold constant workplace, basic demographics, and residential location. Social norms found to influence individual use of alternative commute modes involved the commute behavior and attitudes of close social ties and the situational relevance of social ties' commute behavior. These behavior-related social norms, coupled with past transportation experience and mediated by perceptions and feelings, were found to be helpful in explaining commute mode choice. Implications for social interventions that encourage use of alternative transportation modes are discussed.
\end{abstract}

Keywords: Transportation mode choice, Social norms, Close social ties, Situational relevance, Past transportation experience, Social interventions

$\mathrm{D}$ ependence on cars $^{1}$ for most personal transportation needs, in the United States, has led to multiple social and environmental problems (Abrahamse, Steg, Gifford, \& Vlek, 2009; Buehler $\&$ Pucher, 2011). Mitigating these negative impacts will require individuals to significantly reduce their car use (Flamm, 2009; Goodall, 2010; Shulman, Deyette, Ekwurzel, Friedman, Mellon, Rogers, \& Shaw, 2012), including a shift to alternative transportation modes for different daily-life functions (Buehler \& Pucher, 2011; Maizlish, Woodcock, Co, Ostro, Fanai, \& Fairley, 2013; Schiller, Bruun, \& Kenworthy, 2010). Insights from research on transportation and other human behaviors can help shape behavioral public administration approaches that encourage alternative transportation ${ }^{2}$ mode choices.

\footnotetext{
${ }^{*}$ Connected to Place, San Francisco, U.S.

Address correspondence to Matt Biggar at (mtbiggar@gmail.com)

Copyright: (c) 2019. The authors license this article under the terms of the Creative Commons Attribution 4.0 International License.
}

Transportation behavior scholars have often examined how individuals weigh the costs and benefits of different transportation options primarily related to time, money and convenience (e.g.: Bamberg, Ajzen \& Schmidt, 2003). However, these rational choice variables only partly explain personal transportation choices (Bamberg, Fujii, Friman, \& Gärling, 2011; Morris \& Guerra, 2014; Sherwin, Chatterjee, \& Jain, 2014) as found across many human decisions and behavioral choices (Nørgaard, 2018). Hence interest in examining new variables to explain transportation behavior has emerged (Di Ciommo, Comendador, López-Lambas, Cherchi, $\&$ de Dios Ortuzar, 2014), in particular, social context and subjective experience (Sherwin et al., 2014; St-Louis, Manaugh, van Lierop, \& El-Geneidy, 2014).

\section{Theoretical Framework}

\section{Social Norms}

To explain pro-environmental, altruistic, and health-oriented human behaviors, the Theory of Planned Behavior specifies social norms, in addition to attitudes toward the behavior, as producing 
intentions that lead to behavior (Bandura, 2004). Social norms can be defined as rules and standards that are socially derived and guide or constrain our behavior (Cialdini \& Trost, 1998). These can include subjective norms: the attitudes and expectations of others towards a specified behavior (Ajzen, 1991); and descriptive norms: standards that develop from our observations of others' behavior (Cialdini, Reno, \& Kallgren, 1990).

Research to better understand social influence specific to transportation choices is limited (Di Ciommo et al., 2014; St-Louis et al., 2014). In exploring the social context for bicycling in 12 municipalities across England, Sherwin, et al. (2014) noted that the majority of new regular bicyclists mentioned partners and other family members who biked, while those who rarely cycled shared mostly about the negative biking experiences of others in their social network. Building on this research, this study examines the influence of social norms involving the behavior and attitudes of close social ties_-family, friends and colleagues_on commute mode choice.

The situational relevance between individuals may be particularly important to whether social norms influence commute mode choice. Using an alternative commute mode, for example, can be more difficult for an individual who has young children to take to school compared to a close social tie without such responsibilities.

\section{Past Transportation Experience}

Past transportation choices serve as a primary influence on future choices (Bamberg, Ajzen, \& Schmidt, 2003). 'Bounded rationality' (Diamond \& Vartiainen, 2012; Kahneman, 2003, 2011), or incomplete information processing, can occur if one views a new or different transportation alternative largely based on perceptions from past experience. When such perceptions are connected with negative emotions and feelings, they may bias an individual away from choosing an alternative transportation mode. Carrus, Passafaro, and Bonnes (2008) found that negative anticipated emotions and past experience were significant predictors of intention to use public transportation. In the study by Sherwin et al. (2014), the non-regular bicyclists discussed negative bicycling incidents in the past in detail while similar negative stories were not recounted by regular bicyclists.

\section{Social Interventions}

Although social interventions have been found effective in changing transportation behavior, many gaps in knowledge exist about when and why they are effective (Richter, Friman, \& Gärling, 2011). Theoretical grounding for such measures is needed (Bamberg et al., 2011). A better understanding of how social norms and past transportation experience are associated with commute mode choice may help shape interventions that increase use of alternative commute modes.

\section{Study and Methods}

\section{Setting and Sample}

This study involved Stanford University employees who regularly commuted to the main campus or adjacent medical facilities. The campus is located in a suburban setting within the San Francisco Bay Area of California. Approximately 20,000 people commute to the campus and medical center daily.

To mitigate the selection bias of sampling on the dependent variable (McAdam \& Paulsen, 1993; Smilde, 2005), five drive-alone commuters and five alternative-mode commuters were selected for the study from a database of employees. ${ }^{3}$ The individuals in each pair were matched by residential location, age, gender, family situation, and work hours (see Table 1; pseudonyms are used for each individual to protect their confidentiality). Matching by these characteristics helped hold constant socio-demographic and situational factors (Bamberg, Fujii, Friman, \& Gärling, 2011) that may influence commute mode choice and facilitated the exploration of social and subjective influences on commute mode choice.

\section{Data Collection and Analysis}

Each commuter participated in two in-depth interviews over the three-month study to elicit data on their experience commuting and what influenced their mode choice. Each interview lasted 45 minutes to one hour. A primary purpose of the narrative interviewing was to capture the lived experience of individuals and reveal processes (Seidman, 2012; Weiss, 1995) around participants' commute decisions. The interviewer asked and prompted participants to describe their commute experience; describe feelings and thoughts related to it; and share the context around their commute mode choice including the behavior of their close social 
Table 1

Study Sample Characteristics for Matched Pairs

\begin{tabular}{|c|c|c|c|c|c|c|c|}
\hline & $\begin{array}{l}\text { Place of Resi- } \\
\text { dence; Com- } \\
\text { mute Distance } \\
\text { (one-way) }\end{array}$ & Individual & $\begin{array}{l}\text { Primary } \\
\text { Commute } \\
\text { Mode }\end{array}$ & $\begin{array}{l}\text { Age } \\
\text { Range }\end{array}$ & Gender & Family Situation & $\begin{array}{c}\text { Typical Work } \\
\text { Hours }\end{array}$ \\
\hline \multirow[t]{2}{*}{ Pair A } & $\begin{array}{l}\text { San Jose; } \\
25 \text { miles }\end{array}$ & Diana & Train/Walk & $31-40$ & Female & $\begin{array}{c}\text { Married, } \\
\text { with } 2 \text { elementary- } \\
\text { aged children }\end{array}$ & $\begin{array}{l}\text { 7:20AM to } \\
\text { 4:20PM }\end{array}$ \\
\hline & & Elizabeth & Drive alone & $41-50$ & Female & $\begin{array}{l}\text { Married, } \\
\text { with } 1 \text { elementary- } \\
\text { aged child }\end{array}$ & $\begin{array}{c}\text { 7:00AM/8:00AM } \\
\text { to } \\
\text { 4:00PM/5:00PM }\end{array}$ \\
\hline \multirow[t]{2}{*}{ Pair B } & $\begin{array}{l}\text { San Francisco; } \\
35 \text { miles }\end{array}$ & Frank & Bike/Train & $31-40$ & Male & $\begin{array}{c}\text { Married, } \\
\text { no children }\end{array}$ & $\begin{array}{c}9: 30 \mathrm{AM} \text { to } \\
5: 30 \mathrm{PM}\end{array}$ \\
\hline & & Vince & Drive alone & $31-40$ & Male & $\begin{array}{l}\text { Married, } \\
\text { no children }\end{array}$ & $\begin{array}{l}\text { 8:15AM to } \\
\text { 5:00PM }\end{array}$ \\
\hline \multirow[t]{2}{*}{ Pair C } & $\begin{array}{l}\text { Palo Alto; } \\
3 \text { miles }\end{array}$ & Kathy & Bike & $60+$ & Female & $\begin{array}{c}\text { Married, } \\
1 \text { post high school } \\
\text { aged child } \\
\end{array}$ & $\begin{array}{l}\text { 9:00AM to } \\
\text { 6:00PM }\end{array}$ \\
\hline & & Barbara & Drive alone & $51-60$ & Female & $\begin{array}{c}\text { Married, } \\
2 \text { post-high-school- } \\
\text { aged children }\end{array}$ & $\begin{array}{l}\text { 8:00AM to } \\
\text { 5:00PM }\end{array}$ \\
\hline \multirow[t]{2}{*}{ Pair D } & $\begin{array}{l}\text { Mountain View; } \\
12-13 \text { miles }\end{array}$ & Allison & Train/Bus & $31-40$ & Female & $\begin{array}{c}\text { Single, } \\
\text { no children }\end{array}$ & $\begin{array}{c}\text { 8:30AM to } \\
5: 30 \mathrm{PM}\end{array}$ \\
\hline & & Miranda & Drive alone & $41-50$ & Female & $\begin{array}{l}\text { Single, } \\
\text { no children }\end{array}$ & $\begin{array}{l}\text { 10:00AM to } \\
\text { 6:00PM }\end{array}$ \\
\hline \multirow[t]{2}{*}{ Pair E } & $\begin{array}{l}\text { Fremont; } \\
20 \text { miles }\end{array}$ & Gary & Bus & $41-50$ & Male & $\begin{array}{c}\text { Married, } \\
\text { post-high school } \\
\text { age children }\end{array}$ & $\begin{array}{l}\text { 7:30AM to } \\
\text { 4:30PM }\end{array}$ \\
\hline & & Louis & Drive alone & $31-40$ & Male & $\begin{array}{c}\text { Married, } \\
1 \text { elementary } \\
\text { school-aged child, } \\
\text { spouse who trans- } \\
\text { ports child }\end{array}$ & $\begin{array}{c}\text { 6:00AM to } \\
\text { 3:00PM/4:00PM }\end{array}$ \\
\hline
\end{tabular}

ties and attitudes of those ties towards the interviewee's chosen commute mode.

The coding process involved multiple stages conducted by the interviewer (primary researcher) as well as a secondary researcher. Axial coding was used to develop thematic categories inductively in an effort to find some coherence in the coded data (Corbin \& Strauss, 1990). The main categories that emerged from this process were past transportation experience and social norms. Coded data was then compared between the drive-alone commuters and alternative-mode commuters.

\section{Results}

Social Norms:

Behavior and Attitude of Close Social Ties

Alternative-mode commuters in the study had close social ties-family, friends and colleagueswho commuted on alternative modes (see Table 2a). Commuting by train was a frequent topic in Diana's office, as her colleagues who lived in same city also took the train to get to the university. Frank's partner used biking as her primary transportation mode, and colleagues at his office, including two of similar 
age and employment status, also biked to work. In discussing the importance of biking to her family, Kathy stated:

"All three of us bike; it's not like I'm the only one... the odd man out."

Specific to commuting, Kathy mentioned two of her colleagues who biked to work, referring to that group as "our little unit of the three of us."

In contrast, most social ties of drive-alone commuters used single-occupancy vehicles for commuting and other transportation needs, and many of these ties shared negative views towards or reluctance to use alternative transportation modes (see Table 2b). Most everyone whom Elizabeth knew drove to work. She explained how she tried unsuccessfully to get her sister, who also worked at the university, to carpool with her:

"I actually tried to get her to do it, but she didn't like the idea that we had one parking permit and had to trade it between the cars."

Vince summed up the commute behavior of his office of approximately 30 co-workers, stating, "Pretty much everyone here is driving." Barbara's husband, son and daughter primarily commuted and traveled by car. Thinking about when she started to drive to work as a young adult, she recalled how biking was viewed negatively among her peers:

"Then, of course, at a young age, you go to college. You come back. The last thing you're doing is riding bikes. That's kiddie stuff. I've got bars to go to after work with adult people."

Miranda's husband and colleagues also drove to work. She shared that "pretty much everyone drives in [her work] department. Louis discussed his friends' transportation experiences:

"Most of the time, my friends, none of us take public transportation. I don't know if they do it in their lives, but when any of us get together, it's always driving."

His boss and many colleagues - most of whom have a similar work schedule-drove to work. His family and some colleagues frequently complained about public transportation. Thus, the transportation-specific attitudes and behaviors of close social ties of the drive-alone commuters seemed to operate largely as social norms opposed to alternative commute modes.

At the same time, drive-alone commuters had some social ties who commuted using alternative modes. Vince shared the following about his friends' commuting:

\footnotetext{
"The people I know-my wife and our friends who live and work in the city-they all take public transit. I mean, that's just what it is... Then, friends who work out of the city, most of them are taking [employer-provided] tech shuttles." 4
}

He emphasized, however, that the commute situation of these close social ties was not comparable to his own. Drive-alone commuters generally viewed their social ties who commuted using alternative modes as not relevant to their situation and consequently less influential on their commute mode choice.

\section{Past Transportation Experience}

Some drive-alone commuters negatively viewed alternative transportation experiences from the past. Louis recalled seeing "crazy people" and feeling his personal space was "heavily cramped" on the regional subway, BART. Regarding an effort to carpool with a co-worker, he remembered how his coworker complained a lot in the car and wanted to leave work earlier than he did during this threeweek experience. Miranda recounted past experiences such as the stress of missing a train. Elizabeth commuted by train to a previous employer for a brief period but felt she got sick a lot during that period, which she attributed to germ exposure on the train. Perceptions and feelings from these past alternative transportation experiences served as barriers for these individuals to use alternative commute modes.

All of the alternative-mode commuters had many years of positive and satisfactory experience commuting on alternative modes. Diana had been commuting by train and walking to work for ten years, enjoying the time to read, socialize, exercise, and reduce stress. Allison had been using public transportation since college and noted how it worked well for her time, finances, and overall enjoyment. Gary had been commuting by bus for ten 
Table 2a

Commute Behavior and Attitudes of Social Ties to Alternative-Mode Commuters

\begin{tabular}{ccll}
\hline Commuter & $\begin{array}{c}\text { Primary } \\
\text { Commute } \\
\text { Mode }\end{array}$ & $\begin{array}{c}\text { Social Ties Who Use Commute } \\
\text { Alternatives }\end{array}$ & $\begin{array}{c}\text { Social Ties Who Commute in } \\
\text { Single-Occupancy Vehicles }\end{array}$ \\
\hline Frank & Bike/Train & $\begin{array}{l}\text { Wife, colleagues of similar age and sta- } \\
\text { tus }\end{array}$ & \\
\hline Diana & Train/Walk & $\begin{array}{l}\text { Commute buddy; colleagues from } \\
\text { same residential location; family }\end{array}$ & $\begin{array}{l}\text { Colleagues who live closer; neigh- } \\
\text { bors who envy her commute }\end{array}$ \\
\hline Gary & Bus & Children at college & $\begin{array}{l}\text { Colleagues who live elsewhere, fi- } \\
\text { ancé }\end{array}$ \\
\hline Allison & Train/Bus & Some colleagues and friends on train & Some colleagues; family members \\
\hline Kathy & Bike & $\begin{array}{l}\text { Son and husband; friends/book club; } \\
\text { women of similar age in bike course; } \\
\text { students notice her biking; two col- } \\
\text { leagues }\end{array}$ & $\begin{array}{l}\text { Husband (commutes); other col- } \\
\text { leagues }\end{array}$ \\
\hline
\end{tabular}

Table $2 b$

Commute Behavior and Attitudes of Social Ties to Drive-Alone Commuters

\begin{tabular}{|c|c|c|c|}
\hline Commuter & $\begin{array}{c}\text { Primary } \\
\text { Commute } \\
\text { Mode }\end{array}$ & $\begin{array}{c}\text { Social Ties Who Use Commute } \\
\text { Alternatives }\end{array}$ & $\begin{array}{l}\text { Social Ties Who Commute in } \\
\text { Single-Occupancy Vehicles }\end{array}$ \\
\hline Vince & Drive alone & $\begin{array}{l}\text { Wife and friends who work in same } \\
\text { city where they live use subway; } \\
\text { friends use 'tech shuttles' }\end{array}$ & Colleagues \\
\hline Elizabeth & Drive alone & None & Most everyone she knows \\
\hline Louis & Drive alone & $\begin{array}{l}\text { Some colleagues who live elsewhere; } \\
\text { mother-in-law }\end{array}$ & $\begin{array}{l}\text { All friends; boss; most colleagues; } \\
\text { family and colleagues- negative } \\
\text { views of public transportation }\end{array}$ \\
\hline Miranda & Drive alone & $\begin{array}{l}\text { Friends who use 'tech shuttles'; co- } \\
\text { worker in the past }\end{array}$ & $\begin{array}{l}\text { Husband and colleagues; friends } \\
\text { grumble about CalTrain; hiking } \\
\text { group members all drive }\end{array}$ \\
\hline Barbara & Drive alone & $\begin{array}{l}\text { Some colleagues take train from fur- } \\
\text { ther away }\end{array}$ & $\begin{array}{l}\text { Husband and kids; most colleagues; } \\
\text { office culture; colleague had bike } \\
\text { stolen; social circle view of biking as } \\
\text { 'kiddie' stuff }\end{array}$ \\
\hline
\end{tabular}

years and hoped he would not have to commute by car again:

"If I ever had to go back to driving — and it's not like our roadways are going to get any less congested in the foreseeable future-it would be painful."

Frank had enjoyed commuting by bike and public transportation in locations such as Washington, D.C., Boston, and Copenhagen. Kathy had been commuting by bike for almost thirty-five years. These long-term, positive past experiences with alternative transportation modes differed considerably from the past experiences of the drive-alone commuters.

\section{Readiness for Social Interventions}

Data emerged in this study that indicated a readiness for social interventions by some drive-alone commuters. Barbara, for example, explained that 
she needed someone to "push her" and "support her" in moving away from her "28-year driving habit." She talked about interest in taking the bus and explained how someone could help her get started:

"I would love it if someone sat with me and talked through the bus option with me. 'I can show you exactly what that would look like in the way of you taking this bus. It'll come to here."'

At the start of the interview process, Louis stated that there was no possible way that he would take public transportation. However, following the interviews, he contacted the interviewer to say that he was going to try the bus. Vince also started the interview process by talking about alternative commuting: "I wouldn't - it has never even occurred to me to do it". Yet, later in the process, he talked about carpooling and expressed interest in exploring the bike-train combination to get to work. The influence of the interview process on these three drive-alone commuters provided additional evidence for the potential importance of social interventions in changing transportation behavior.

\section{Discussion and Conclusion}

By matching drive-alone commuters and alternative-mode commuters, holding other variables constant within these pairs, and using qualitative data to study relationships among variables, this study's findings add to the growing body of research on the limits of rational choice theory in explaining personal transportation behavior (Di Ciommo et al., 2014; Sherwin et al., 2014; St-Louis, Manaugh, Van Lierop, \& El-Geneidy, 2014) and overall human behavior (Nørgaard, 2018). Drive-alone commuters viewed commute mode alternatives much less favorably than alternative-mode commuters. Past transportation experience and social norms, related to close social ties, seemed to explain these differing perceptions that influenced mode choice.

To add to the emerging research on social context and transportation behavior research (Carrasco \& Farber, 2014; Di Ciommo et al., 2014; Sherwin et al., 2014), social norms that guide and constrain behavior (Bandura, 2004; Cialdini \& Trost, 1998) provided useful ways to better understand personal transportation choices. Similar to the subjective norm from the Theory of Planned
Behavior (Ajzen, 1991), the attitudes of close social ties-family, friends and colleagues-towards commute alternatives appeared to be influential on commute mode choice. Consistent with research studies on descriptive norms (Cialdini et al., 1990), the commute behavior of close social ties who had situational relevance, or relevance to the individual's geographic, work, family and life-stage situation, also appeared to explain commute mode choice.

These findings also extend understanding of the importance of the relationship between past transportation behavior and current and future behavior (Bamberg et al., 2003; Carrus et al., 2008). Similar to how regular and non-regular bicyclists discussed past experience in the study by Sherwin et al. (2014), drive-alone commuters discussed negative aspects of alternative transportation experiences in the past while alternative-mode commuters did not recount similar negative stories.

Possibilities for changing transportation habits, deeply rooted in past experience and social context, also emerged in this study. Drive-alone commuters were not diametrically opposed to alternative commute modes. The interview process, though unintended, became the beginning of a socially mediated intervention for three of the drivealone commuters. These individuals moved towards an intention to use an alternative commute mode through having time to explore options and talk openly to another person.

\section{Implications for Social Interventions}

This study's findings suggest direction for social interventions as means to shift perceptions around transportation alternatives (Bamberg et al., 2011; Steg \& Vlek, 2009) and increase use of alternative commute modes. The factors that were held relatively constant in matched pairs in this study may provide useful criteria for matching individuals in a social intervention by situational relevance specific to commute behavior. By carefully matching drivealone commuters to alternative-mode commuters, the likelihood increases of the targeted individual viewing the commute mode choice of another as realistic to their situation and feeling encouraged to change. Once individuals are matched in pairs or groups, social interventions may facilitate time forindividuals to consider transportation mode options, think through logistical challenges, and learn from and with one another. Bamberg et al. (2003) refers to this as the intention formation process and 
frames it as time for intensive reasoning around potential barriers and more detailed planning. With interventions that leverage social norms via situationally-relevant social ties and provide time for reflection and contemplation of one's transportation choices, individuals may be able to change their commute mode perceptions and behavior.

\section{Acknowledgments}

The author would like to thank Stanford University Graduate School of Education, Stanford Parking and Transportation Services and especially Associate Professor Nicole M. Ardoin (Stanford Graduate School of Education and Woods Institute for the Environment) for their support of this research. This study was conducted under the auspices of Stanford University's Institutional Review Board and followed guidelines for dealing with human subjects.

\section{Notes}

1. Cars and light trucks are used for more than $80 \%$ of personal trips in the US (Buehler \& Pucher, 2011; Shulman et al., 2012). Canada and Australia also use cars and lights trucks for over $80 \%$ of personal travel, while cars and light trucks account for 45 to $70 \%$ of personal travel in different Western European countries (Buehler \& Pucher, 2011)

2. Alternative transportation refers to all transportation modes other than single-occupancy vehicles [SOVs].

3. The organization's database, used for this study, derives from two separate groups of employees. Those participating in the university's Commute Club comprised the alternative-mode commuters. The drive-alone commuter pool included those who have parking permits for the workplace, yet do not have special parking privileges for carpooling.

4. Many technology companies with large offices in the San Francisco Bay Area (e.g., Google, Apple, Facebook, and Genentech) provide free, private shuttle buses for their employees to facilitate commuting.

\section{References}

Abrahamse, W., Steg, L., Gifford, R., \& Vlek, C. (2009). Factors influencing car use for commuting and the intention to reduce it: A question of self-interest or morality? Transportation Research Part F: Traffic Psychology and Behaviour, 12(4), 317-324.

Ajzen, I. (1991). The theory of planned behavior. Organirational Behavior and Human Decision Processes, 50(2), 179-211.

Bamberg, S., Ajzen, I., \& Schmidt, P. (2003). Choice of travel mode in the theory of planned behavior: The roles of past behavior, habit, and reasoned action. Basic and Applied Social Psychology, 25(3), 175-187.

Bamberg, S., Fujii, S., Friman, M., \& Gärling, T. (2011). Behaviour theory and soft transport policy measures. Transport Policy, 18(1), 228-235.

Bamberg, S., \& Möser, G. (2007). Twenty years after Hines, Hungerford, and Tomera: A new metaanalysis of psycho-social determinants of pro-environmental behaviour. Journal of Environmental Psychology, 27(1), 14-25.

Bandura, A. (2004). Health promotion by social cognitive means. Health Education and Behavior, 31(2), 143-164.
Bell, S. E. (2008). Photovoice as a strategy for community organizing in the central Appalachian coalfields. Journal of Appalachian Studies, 14(1/2), 34-48.

Buehler, R., \& Pucher, J. (2011). Sustainable transport in Freiburg: lessons from Germany's environmental capital. International Journal of Sustainable Transportation, 5(1), 43-70.

Carrasco, J., \& Farber, S. (2014). Editorial: Selected papers on the study of the social context of travel behaviour. Transportation Research Part A: Policy and Practice, (68), 1-2.

Carrus, G., Passafaro, P., \& Bonnes, M. (2008). Emotions, habits and rational choices in ecological behaviours: The case of recycling and use of public transportation. Journal of Environmental Psychology, 28, 51-62. doi:10.1016/j.jenvp.2007.09.003

Cialdini, R. B., Reno, R. R., \& Kallgren, C. A. (1990). A focus theory of normative conduct: Recycling the concept of norms to reduce littering in public places. Journal of Personality and Social Psychology, 58(6), 1015.

Cialdini, R. B., \& Trost, M. R. (1998). Social influence: Social norms, conformity and compliance. 
Corbin, J. M., \& Strauss, A. (1990). Grounded theory research: Procedures, canons, and evaluative criteria. Qualitative Sociology, 13(1), 3-21.

Di Ciommo, F., Comendador, J., López-Lambas, M. E., Cherchi, E., \& de Dios Ortuzar, J. (2014). Exploring the role of social capital influence variables on travel behaviour. Transportation Research Part A: Policy and Practice, 68, 46-55.

Diamond, P., \& Vartiainen, H. (2012). Behavioral economics and its applications. Princeton, NJ: Princeton University Press.

Ewing, R., \& Cervero, R. (2010). Travel and the built environment: a meta-analysis. Journal of the American Planning Association, 76(3), 265-294.

Flamm, B. (2009). The impacts of environmental knowledge and attitudes on vehicle ownership and use. Transportation Research Part D: Transport and Environment, 14(4), 272-279.

Froehlich, J., Dillahunt, T., Klasnja, P., Mankoff, J., Consolvo, S., Harrison, B., \& Landay, J. A. (2009). UbiGreen: Investigating a mobile tool for tracking and supporting green transportation habits. Paper presented at the SIGCHI Conference on Human Factors in Computing Systems, New York, NY.

Goodall, C. (2010). How to live a low-carbon life: the individual's guide to tackling climate change. New York: Earthscan.

Heller, M. C., \& Keoleian, G. A. J. J. o. I. E. (2015). Greenhouse gas emission estimates of US dietary choices and food loss. Journal of Industrial Ecology 19(3), 391-401.

Hines, J., Hungerford, H., \& Tomera, A. (1986). Analysis and synthesis of research on responsible environmental behavior: a meta-analysis. Journal of Environmental Education, 18(2), 1-8.

Kahneman, D. (2003). Maps of bounded rationality: Psychology for behavioral economics. American Economic Review, 1449-1475.

Kahneman, D. (2011). Thinking, fast and slow. New York, NY: Farrar, Straus and Giroux.

Lindenberg, S., \& Steg, L. (2007). Normative, gain and hedonic goal frames guiding environmental behavior. Journal of Social Issues, 63(1), 117-137.

Maizlish, N., Woodcock, J., Co, S., Ostro, B., Fanai, A., \& Fairley, D. (2013). Health co-benefits and transportation-related reductions in greenhouse gas emissions in the San Francisco Bay Area. American Journal of Public Health, 103(4), 703-709.

McAdam, D., \& Paulsen, R. (1993). Specifying the relationship between social ties and activism. American journal of sociology, 99(3), 640-667.

Morris, E. A., \& Guerra, E. (2014). Mood and mode: does how we travel affect how we feel? Transportation, 42(1), 25-43.

Nørgaard, A. S. (2018). Human behavior inside and outside bureaucracy: Lessons from psychology. Journal of Behavioral Public Administration, 1(1).
Ouellette, J. A., \& Wood, W. (1998). Habit and intention in everyday life: the multiple processes by which past behavior predicts future behavior. Psychological Bulletin, 124(1), 54.

Putnam, R. D. (2001). Bowling alone: The collapse and revival of American community. New York, NY: Simon and Schuster.

Richter, J., Friman, M., \& Gärling, T. (2011). Soft transport policy measures: Gaps in knowledge. International Journal of Sustainable Transportation, 5(4), 199-215.

Schiller, P. L., Bruun, E., \& Kenworthy, J. R. (2010). An Introduction to sustainable transportation: Policy, planning and implementation. Washington, DC: Earthscan.

Schussman, A., \& Soule, S. A. (2005). Process and protest: Accounting for individual protest participation. Social Forces, 84(2), 1083-1108.

Seidman, I. (2012). Interviewing as qualitative research: $A$ guide for researchers in education and the social sciences. New York, NY: Teachers College Press.

Sherwin, H., Chatterjee, K., \& Jain, J. (2014). An exploration of the importance of social influence in the decision to start bicycling in England. Transportation Research Part A: Policy and Practice, 68, 32-45.

Shulman, S., Deyette, J., Ekwurzel, B., Friedman, D., Mellon, M., Rogers, J., \& Shaw, S. (2012). Cooler smarter: Practical steps for low-carbon living. Washington, DC: Island Press.

Smilde, D. (2005). A qualitative comparative analysis of conversion to Venezuelan evangelicalism: How networks matter. American Journal of Sociology, 111(3), 757-796.

St-Louis, E., Manaugh, K., van Lierop, D., \& El-Geneidy, A. (2014). The happy commuter: A comparison of commuter satisfaction across modes. Transportation Research Part F: Traffic Psychology and Behaviour, 26, 160-170.

Steg, L., \& Vlek, C. (2009). Encouraging pro-environmental behaviour: An integrative review and research agenda. Journal of Environmental Psychology, 29(3), 309-317.

Tumlin, J. (2011). Sustainable transportation planning: Tools for creating vibrant, healthy, and resilient communities (Vol. 16). Hoboken, NJ: John Wiley \& Sons.

Verba, S., Schlozman, K. L., \& Brady, H. E. (1995). Voice and equality: Civic voluntarism in American politics. Cambridge, MA: Harvard University Press.

Weiss, R. S. (1995). Learning from strangers: The art and method of qualitative interview studies. New York, NY: Simon and Schuster.

Wilson, J. (2000). Volunteering. Annual Review of Sociology, 26, 215-240.

Yin, R. K. (2009). Case study research: Design and methods (Vol. 5). London, UK: Sage. 